\title{
PROLIFERATION ACTIVITY AND NUMBER OF STROMAL (CFU-f) AND HAEMOPOIETIC (CFUS) STEM CELLS IN BONE MARROW AND SPLEEN OF RATS OF DIFFERENT AGES
}

\author{
A. VACEK \\ Institute of Biophysics, Academy of Sciences of the Czech Republic, Brno, Czech Republic
}

Received October 27, 1999

Accepted February 10, 2000

\begin{abstract}
Vacek A.: Proliferation Activity and Number of Stromal and Haemopoietic Stem Cells in Bone Marrow and Spleen of Rats of Different Ages. Acta Vet. Brno 2000, 69: 25-31.

The number and proliferation activity of stromal (CFU-f) and haemopoietic (CFUs) stem cells of the femoral bone marrow and the spleen of Wistar rats of different ages were investigated. CFUs were assayed by the spleen colony technique in irradiated recipient rats. For the determination of numbers of CFU-f an in vitro liquid culture was used. Proliferation activities of both types of cells were evaluated in vivo after intraperitoneal administration of hydroxyurea. The numbers of both CFU-f and CFUs increased in the femoral bone marrow cavity while they decreased in the spleen within the period from one to five months of the rat age. The total number of nucleated cells per marrow cavity of the femur was higher in the aged rats than in the young ones, in the spleen only slight differences were observed with advancing age of rats. It may be thus concluded that the compartment size of CFU-f and CFUs increases in the bone marrow and decreases in the spleen during the aging. Proliferation activities of both CFU-f and CFUs decreased substantially with time when the populations of both cells reached the size which is maintained in adult haemopoietic organs. After sublethal gamma irradiation the recovery of CFU-f has preceded the recovery of CFUs in both the bone marrow and the spleen. The relationship between the stromal stem cells (CFU-f) proliferation and the state of haemopoiesis is discussed.
\end{abstract}

Haemopoiesis, rat, age, haemopoietic stem cells (CFUs), stromal stem cells ( $C F U-f)$, proliferation activity, hydroxyurea $(\mathrm{HU})$

In the bone marrow of adult mammals blood cells develop within a complex regulatory network of humoral, cellular and matrix factors (Dexter et al. 1983; Tavasoli and Friedenstein 1983). During the postnatal development the locations of active haemopoiesis change: while the role of the liver in the haemopoiesis decreases very rapidly in the postnatal life in all mammals (Versele et al. 1987), the haemopoietic activity of the spleen is high in mice during the whole life span (Silini and Andreozzi 1974) but in rats decreases already during the age of maturation (V acek et al. 1976). This suggests that also the microenvironmental conditions in the bone marrow and spleen are changing during the aging of rats. In normal adult mammals haemopoietic stem cells and progenitor cells reside in the bone marrow where they are in an intimate contact with bone marow stroma (Trentin 1970). One of the components of the haemopoietic cellular elements of the stroma is the CFU-f-population, which can be detected among the haemopoietic tissue cells by an in vitro liquid culture system where the CFU-f cells give rise to colonies of adherent fibroblast-like cells (Gordon 1988; Friedenstein et al. 1970; Kolesnikova and Smirnov 1985). The adherent population of the cells of haemopoietic environment is heterogeneous and contains macrophages, fibroblasts, endothelial and adipocyte-like cells (Versele et al.1987; Sullivan et al.1989; Song and Quesenberry 1984). These cells are capable of transferring the microenvironment when transplanted (Friedenstein et al. 1974) and after prolonged cultivation of the adherent cells in vitro the hemopoiesis is maintained for 
several weeks as measured by production of granulocyte-macrophage (GM-CFC) and erythroid (BFUe) progenitor cells (Song and Queseberry 1984; Testa and Dexter 1979; Brockbank and van Peer 1983).

Our previous experiments demonstrated (Vacek et al. 1975, 1976) changes in the CFUs compartment of the bone marrow and spleen of rats during postnatal development. The purpose of this study was to characterize the proliferation activity and the size of the compartment of the stromal stem cells (CFU-f) in the bone marrow and spleen of rats of different ages and to evaluate the relationship between the CFU-f and CFUs in the haemopoietic activity of both tissues. The results show evidence of intrinsic changes in the proliferative activity of CFU-f compartment in the course of 7 month of age and indicate on the relation of changes in the compartment of CFU-f to the haemopoietic activity in normal life and after irradiation.

Animals

\section{Materials and Methods}

Male rats of the Wistar strain aged from 1 to 7 months were used throughout this study. They were kept in cages containing 5 animals each and fed with sterilized DOS-2st diet (Velaz). Water acidified to $\mathrm{pH}$ 2.0-3.0 and food were given ad libitum. The rats were kept under controlled lighting conditions (LD 12:12) at a temperature of $22 \pm 1{ }^{\circ} \mathrm{C}$. The experiments were conducted according to the principles enunciated in the Guide for Care and Use of Laboratory Animals issued by the Czech Society for Laboratory Animal Science

Irradiation

Irradiation was carried out using a Chisostat source of ${ }^{60} \mathrm{Co}$ radiation at the dose rate of $0.4 \mathrm{~Gy} / \mathrm{min}$.

Stem cell assay systems

(i) Assay of the spleen colony-forming cells. Spleen colony-forming units (CFUs) were counted on day 12 of their development using the method of Till and McCulloch (1961) in our modification (Vacek et al. 1975). CFUs were determined after transplantation of donor marrow or spleen cells into host rats aged one month (and 15 rats per group were used as recipients), which had received a single dose of 8.0 Gy to suppress the host haemopoiesis. For the preparation of suspension of the haemopoietic tissue three to five rats were used as donors.

(ii) Stromal stem cells assay (CFU-f). CFU-f cells were assayed by a tissue culture method of Frieden stein et al. (1970) in our modification ( V acek et al. 1990ab). The complete tissue culture medium consisted of alphaMeM medium (Sigma, USA) supplemented with $10 \%$ foetal calf serum, antibiotics (1000U penicillin, $100 \mu \mathrm{g} / \mathrm{ml}$ streptomycin) and $1.2 \mathrm{mg} / \mathrm{ml}$ glutamine (Sevapharma, Praha). The cells were plated in triplicate on plastic Petri dishes (diameter $60 \mathrm{~mm}$, KOH-I-NOOR, Hardtmuth, Dačice) containing $5 \mathrm{ml}$ of tissue culture medium. The final concentration of seeded cells varied between $5 \times 10^{5}$ and $1 \times 10^{6}$ nucleated cells per $\mathrm{ml}$ and was chosen on the basis of preliminary experiments to yield enough colonies to allow correct statistical evaluation of the data. Dishes were incubated at $37{ }^{\circ} \mathrm{C}$ in a humidified atmosphere containing $5 \% \mathrm{CO}_{2}$ (Forma Scientific, USA). The medium was totally renewed on day 3 of cultivation, which was terminated on day 10 after seeding. The cells were then fixed with 5\% glutaraldehyde, stained with Giemsa-Romanowski solution and colonies were scored under a stereo microscope as discrete aggregates of cells ranging in size from 1 to $5 \mathrm{~mm}$. The experiments were performed in triplicates and repeated three times.

(iii) Proliferation rate in the CFUs and CFU-f populations. The numbers of CFUs and CFU-f in the S-phase of the cell cycle were determined using a high dose $(1000 \mathrm{mg} / \mathrm{kg}$ ) of hydroxyurea (HU) (Aldrich-Europe, Jensen Pharmaceutical Laboratories, Belgium) in vivo (Bhuy an et al. 1973; V as sort et al. 1971; Vacek et al. 1990c). HU was dissolved in saline solution immediately before intraperitoneal injection in a volume of $0.5 \mathrm{ml} 90 \mathrm{~min}$ before the removal of the bone marrow and spleen for the CFUs and CFU-f determination. A control group of rats was injected with saline solution instead of HU. The difference between the CFUs and CFU-f contents in the femurs and spleens of the control and HU-injected rats indicated the fraction of cells in the S-phase of the cell cycle at the time of HU injection.

Statistical evaluation

Differences in the numbers of colonies and cellularity of the tissues were evaluated by the $t$-test and correlation coefficients. The regression lines and coefficients were evaluated by the method of least squares.

\section{Results}

The data given in Fig. 1 show a statistically significant $(\mathrm{P}<0.01)$ elevation of the number of nucleated cells in the femur at the age of 3.5 and 7 month as compared with the age of one month, whereas in the spleen only slight age-dependent changes were observed. 
The amounts of the CFU-f and CFUs per $10^{6}$ nucleated cells of both the femur and the spleen (Fig. 2) indicate the highest significant $(P$ $<0.01$ ) rate of changes in the period from one to five months of age. In this period, the amount of CFU-f increased 1.2 times and CFUs 1.5 times in the bone marrow, while CFU-f decreased 15 times and CFU-s 4.5 times in the spleen.

Calculated pools of CFU-f and CFUs in the femur (Fig. 3) show a similar pattern of the increase of their size in dependence on the age (correlation coefficients (r) are +0.83 for CFU-f and +0.81 for CFUs. A maximal increase of both pools in femur (4 times for CFU-f and 4.5 times for CFUs) was observed at the age of five months $(\mathrm{P}<0.01)$.

On the other hand, the size of the pools in the spleen (Fig. 3) decreased with the age of animals ( $r=-0.967$ for CFU-f and -0.936 for CFUs), and the rate of the decrease was higher for splenic CFU-f. A maximal drop of the pool of CFU-f (by 93\%) and CFUs (by $75 \%$ ) in the spleen was reached at the age of five months ( $\mathrm{P}<0.01$ as compared with the age of one month). The correlation coefficients between the numbers of CFU-f and CFUs were 0.998 for the bone marrow and 0.999 for the spleen in rats of one to five months of age, thus indicating a possible relationship between changes of the size of the pools of these haemopoietic cell populations.

Proliferation activity of both CFU-f and CFUs (Fig. 4) decreased by $68 \%$ in the femur until five months of age, while in the spleen the decrease was $86 \%$ for CFU-f

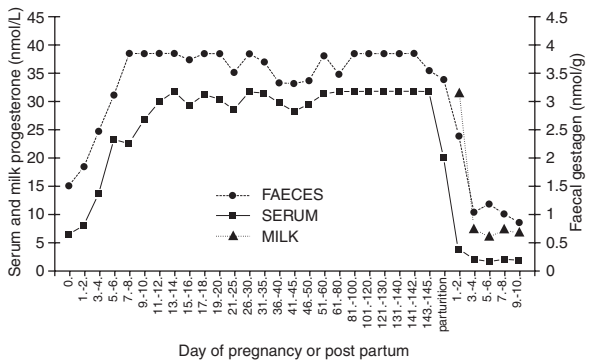

Fig. 2. The number of CFU-f and CFUs in femur and spleen cells of rats of different ages. $\mathrm{X}$ - age of rats in months, $\mathrm{Y}$ - number of CFUper $10^{6}$ nucleated cells and CFUs per $10^{6}$ nucleated cells. Data are he mean of three separate experiments. Sample size per group: three to five donor rats and fifteen recipient rats for the CFUs assay. $\mathrm{a}-\mathrm{P}$ $<0.01$, b- $\mathrm{P}<0.05$ in comparison with the group aged one month. and $70 \%$ for CFUs, as compared to values obtained one month after the birth $(\mathrm{P}<0.01)$. From five to seven months of age the proliferation activity both for bone marrow of the femur and in the spleen further decreased by $12 \%$ for CFU-f and $17 \%$ for CFUs.

Furthermore, changes in the CFU-f and CFUs numbers in adult rats after disturbing the steady state of haemopoiesis by gamma rays were studied. Fig. 5 shows that the compartment of CFUs in the bone marrow of the femur and in the spleen of rats exposed to a sublethal dose of gamma rays $(4.0 \mathrm{~Gy})$ at the age of 5 months decreased in both tissues more markedly $(\mathrm{P}<0.01)$ than that of CFU-f. The return to the values found in the control non-irradiated rats was observed in CFU-f by day 10 after irradiation, while the number of 


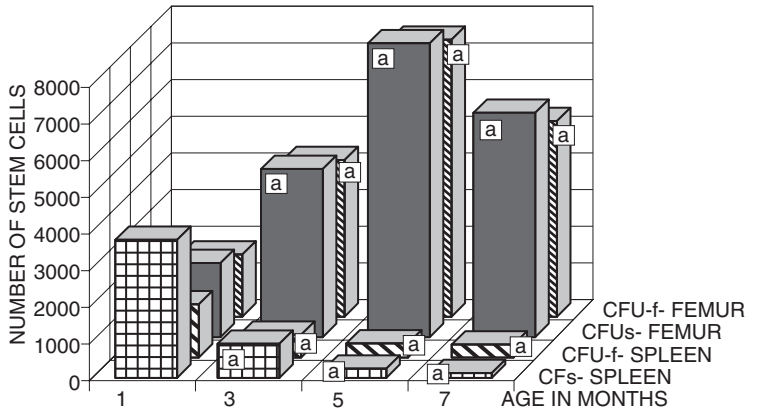

Fig. 3. Age-dependent pool of CFU-f and CFUs in the femur and spleen. X-age in months, Y-number of CFU-f and CFUs in femur and spleen. Each value represents the mean from three separate experiments. $\mathrm{a}-\mathrm{P}<0.01$, as compared with the group aged one month.

CFUs did not reach the level of controls within 21 days of observation. The proliferation activity of CFU-f in the bone marrow of the femur of rats exposed to the sublethal dose of gamma rays increased and declined earlier than that of CFUs, while it remained high in the spleen until the end of observation (data not shown).

\section{Discussion}

A general decrease in haematological values associated with ageing is strain- dependent in mice (at the age over one year) and includes changes in the peripheral blood cells and alteration of the primitive haemopoietic cell compartments (Metcalf and Moore 1971; Williams et al. 1986; de Haan et al. 1997). No differences in the incidence of marrow CFUs were found in mice until one (Kretchmar and Conover 1967; Davis et al. 1968) and two years of age (Williams et al. 1986). Neither any significant difference in the frequency of CFUs was seen in the

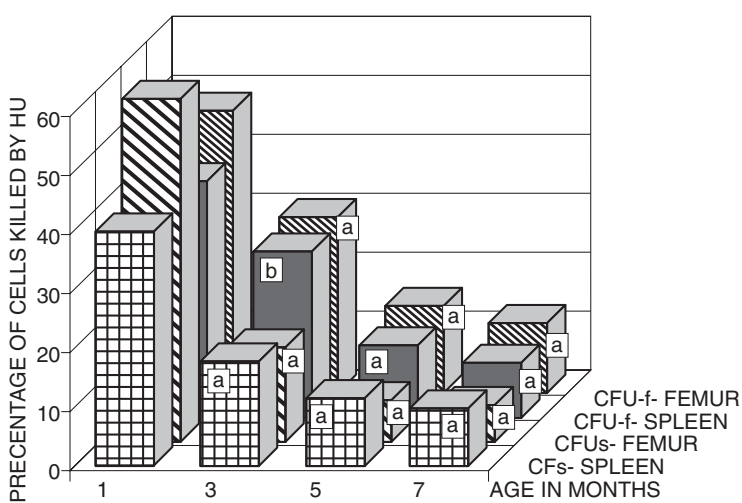

Fig. 4. Proliferation activity of CFU-f and CFUs in femur and spleen of rats from 1 to 7 months of age. X-age of rats in months, Ypercentage of cells killed by HU. Each value represents the mean from three separate experiments .a - $\mathrm{P} 0.01$, b- $\mathrm{P}<0.05$ compared to the group aged one month. spleen but the absolute numbers of CFUs showed a slight reduction in aged mice (Metcalf and Moore 1971; Silini and Andreozzi 1974; Boggs et al. 1986). Endogenous spleen colony-forming capacity also decreased in mice progressively with the age over one year (Yuhas and Storer 1967). However, even in old mice there is the capacity of the spleen to form endogenous colonies of haemopoietic tissue (Yuhas and Storer 1967) and to support the growth of exogenous colonies from the harvested bone marrow transplants.

The data presented in this study show that ageing significantly changes compartments of haemopoietic stem cells in rats. The proliferative activity of haemopoietic stem cells (CFUs) and stromal cells (CFU-f) in rats of Wistar strain sharply decreased during the first five months of life both in the marrow and in the spleen, i.e. in the period of life when only slight fluctuations in the CFUs number are observed in mice (Silini and Andreozzi 1974). The presented results also document that the compartments of CFU-f in the bone marrow and spleen of rats undergo a significant age-dependent reduction that is positively correlated with the changes in CFUs.

The patterns of changes in the concentrations of CFU-f and CFUs in the bone marrow and spleen of rats and their proliferative activities within the age of one to five months show 
statistically significant negative correlation with age $(\mathrm{P}<0.01)$. In both tissues the decrease of proliferation of both CFU-f and CFUs occurs at the time when their populations reach the size which is maintained in the adult haemopoietic organs. In the spleen the reduction of the proliferative activity of haemopoietic stem cells results in the decrease in their number and also in the decrease of the ability of the spleen to support the growth of the transplanted bone marow cells as macroscopically visible spleen colonies (CFUs) (Vacek et al. 1979). When haemopoietic activity of the spleens

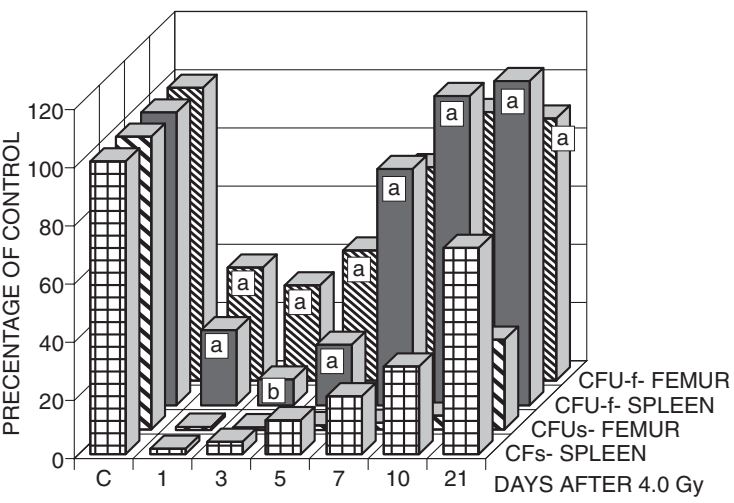

Fig. 5. Temporal response (\% of control) of the haemopoietic (CFUs) and stromal (CFU-f) stem cells in femur and spleen of adult (5-month-old) rats after exposure to $4.0 \mathrm{~Gy}$ of gamma irradiation (total-body irradiation). X- days after irradiation with $4.0 \mathrm{~Gy}$, $\mathrm{Y}$ - percentage of control (C-intact rat of 5 month of age). a- $\mathrm{P}<0.01$, of adults rat (5 month of age) was b- $\mathrm{P}<0.05$ as compared with the percentage of CFUs.

enhanced during the recovery of radiation damage to haemopoiesis, there was a renewal of their ability to support the growth of macroscopic colonies (CFUs) to the level observed at the age of one month (unpublished results).

In the bone marrow the cellularity increased with age as well as the size of the pool of CFUs and CFU-f, while their proliferative activity decreased. These data indicate that in aged rats more slowly dividing stem cells produce an equal number of peripheral blood cells as do more actively cycling but less numerous stem cells in young rats. The increase in the number of primitive haemopoietic cells may be explained as the result of a continued need for production of normal numbers of mature blood cells while their cycling activity is reduced.

Irradiation disturbs the steady state of haemopoietic tissues and results in increased expression of haemopoietic growth regulators (Song and Quesenberry 1984). The stroma of the bone marrow contains several types of adherent regulatory cells producing factors responsible for early stem cell proliferation and for acquisition of receptors for terminal haemopoietic differentiation hormones (Quesenberry et al. 1985). Bone marrow cells recovering after irradiation produce cytokines both activating (Lord et al. 1977), and suppressing (Lord et al. 1976) proliferative processes in the haemopoietic stem cell populations. It has been documented in experiments exploiting the Dexter type tissue culture that activated stromal cells produce cytokines supporting the proliferation of CFUs and the growth of GM-CFC colonies (Song and Quesenberry 1984; Brockbank and Ploemacher 1983; Blackburn and Patt 1977).

In our experiments the irradiation resulted in a decrease of the number of CFU-f and CFUs in both the bone marrow and spleen of rats. A lower decrease of the number of CFU-f colonies after irradiation and their higher recovery rate as compared with CFUs may be due to lower radiosensitivity of CFU-f cells compared with CFUs (Kolesnikova et al. 1993; Song and Quesenberry 1984). The surviving stromal cells increase their proliferation activity during the recovery after sublethal gamma irradiation and may be an important source of the production of cytokines which support the recovery of the radiation-damaged haemopoiesis in the spleen and bone marrow of rats. This observation may indicate that the relationship of the proliferation activity of CFU-f in rats of the Wistar strain to the state of haemopoiesis may be observed not only in the steady state but also in conditons of radiation damage to haemopoiesis. 


\section{Vliv věku potkanů na hemopoetickou aktivitu kostní dřeně a sleziny}

U potkanů kmene Wistar, samců starých 1-7 měsíců, byla sledována hemopoetická aktivita sleziny a kostní dřeně. U zvířat byly metodou transplantace in vivo sledovány počty kmenových buněk krvetvorby ( CFUs) a metodou in vitro stromálních buněk (CFU-f) ve femuru a slezině a jejich proliferační aktivita.

V období od 1 do 5 měsíce věku pool CFUs a CFU-f narůstal ve femuru a klesal ve slezině s následujícím poklesem v obou tkáních. Ve stejném období se snižovala proliferační aktivita CFUs a také CFU-f. Od 5 měsíce věku byl rovnovážný stav krvetvorby potkanů charakterizován v kostní dřeni vysokým počtem CFUs a CFU-f s nízkou proliferační aktivitou, ve slezině byl počet a proliferační aktivita CFUs a CFU-f snížena. Po jednorázovém ozáření dospělých (5 měsíců starých) potkanů gamma paprsky probíhala rychleji úprava stromálních buněk (CFU-f) než kmenových buněk krvetvorby (CFUs), což přispívalo ke stimulaci hemopoetického mikroprostředí a následné úpravě poolu CFUs.

\section{Acknowledgements}

The author is indebted to Dr. A. Bartoníčková and Dr. D. Rotkovská for excellent technical help throughout this study.

\section{References}

BHUYAN, B. K., FRASER, T. J., GREY, L. G., KUENTZEL, S. L., NEIL, G. L. 1973: Cell-kill kinetics of several S-phase specific drugs. Canc. Res. 33: 888-394

BLACKBURN, M. J., PATT, H. M. 1977: Increased survival of haemopoietic pluripotent stem cells in vitro induced by a marrow fibroblast factor. Brit. J. Haematol. 37: 337-344

BOOGS, D. R., PATRENE, K., STEINBERG, H.1986: Aging and hematopoiesis. VI. Neutrophilia and other leukocyte changes in aged mice. Exp. Hematol. 14: 372-379

BROCKBANK, K. G. M., VAN PEER, C. M. J. 1983: Colony-stimulating activity production by hemopoietic fibroblastoid cells in vitro. Acta Haematol. 69: 369-375

BROCKBANK, K. G. M., PLOEMACHER, R. E. 1983: Quantitation of stromal and hemopoietic progenitors in spleen and femoral marrow derived from steel (Slj/+ and Sl/Sld) mice and their normal littermates. Exp. Hematol. 11(6): 467-474

DAVIS, M. L., UPTON, A. C., SATTERFIELD, L. C. 1968: Effect of age of recipient mice on growth and differentiation of transplanted bone-marrow cells. Proc. Soc. exp. Biol. Med. 128: 1149-1153

DEXTER, T. M., SPOONCER, E., VARGA, J., ALLEN, T. D., LANOTTE, M. 1983: Stromal cells and diffusible factors in the regulation of haemopoietic cell development. In: KILLMAN, SV. A. A., CRONKITE, E. P., MULLER-BERAT, C. N., Haemopoietic Stem Cells, A.BenzoSymposium, Munksgaard, Copenhagen, pp. 303-322

FRIEDENSTEIN, A. J., CHAILAKHYAN, R. K., LALYKINA, K. S. 1970: The development of fibroblast colonies in monolayer cultures of guinea-pig bone marrow and spleen cells. Cell Tissue Kinet. 3: 393-403

FRIEDENSTEIN, A. J., CHAILAKHYAN, R. K., LATSINIK, N. V., PANASYUK A. F., KEILISS-BOROK, I

V. 1974: Stromal cell responsible for transfering the microenvironment of the hemopoietic tissues. Transplantation 17: 331-341

GORDON, M.Y.1988: Extracellular matrix of the marrow microenvironment. Brit. J. Haematol. 70:1-8

HAAN, de H., NIJHOF, W., ZANT, G. V. 1997: Mouse strain-dependent changes in frequency and proliferation of hematopoietic stem cells during aging: Correlation between lifespan and cycling activity. Blood 88:15431550

KOLESNIKOVA, A. I., SMIRNOV, A. N. 1985: Tissue cultures in haematology. In: Handbook of Haematology,Vol. 1, ed. Vorobyev A. I. pp. 5-66, Medicina, Moscow (in Russian)

KOLESNIKOVA, A. I, KONOPLANIKOV, A. G, KALSINA, S. Sh., LEPEKHINA, L. A., ZAITSEV, A. V., VAINSON, A. A. 1993: The capacity of rat clonogenic precursor cells of the hemopoietic stroma (CFU-F) to recover from radiation damages. Radiobiologia 33: 236-243 (in Russian)

KRETCHMAR, A. I., CONOVER, W. R. 1967: Note on the reduced number of hemopoietic colonies in spleen of old mice. Exp. Hematol. 14: 48-54

LORD, B. I., MORI, K. J., WRIGHT, E. G., LAJTHA, L. G. 1976: An inhibitor of stem cell proliferation in regenerating bone marrow. Brit. J. Haematol. 34: 441-445

LORD, B. I., MORI, J. K., WRIGHT, E. G.1977: A stimulator of stem cell proliferation in regenerating bone marrow. Biomedicine 27: 223-226

MAUCH, P., BOTNICK, L. E., HANNON, E. C., OBBAGY, J., HELLMAN, S. 1982: Decline in bone marrow proliferative capacity as a function of age. Blood $60: 245-252$

METCALF, D., MOORE, M. A. S. 1971: Haemopoietic cells.North Holland, Amsterdam. 
QUESENBERRY, P., ALBERICO, T., SONG, Z., DONOWITZ, G., STEWARD, M., GUALTIERI, R., BOSWELL, S., McGRATH, E., KLEMAN, E., BARBER, G., CRANSTON, S. 1985: Studies of the regulation of hemopoiesis. Exp. Hematol.13, Suppl.16: 43-48

SILINI, G., ANDREOZZI, U. 1974: Haematological changes in ageing mouse. Exp. Gerontol 9: 99-108

SONG, Z. X., QUESENBERRY, P. J. 1984: Radioresistant murine marrow stromal cells: a morphologic and functional chracterization. Exp. Hematol. 12: 523-533

SULLIVAN, A. K., CLAXTON, D., SHEMATEK, G., WANG, H.1989: Cellular composition of rat bone marrow stroma. Antigen-defined subpopulations. Lab. Invest. 60: 667-676

TAVASOLI, M., FRIEDENSTEIN, A. 1983: Hemopoietic stromal microenvironment. Am. J. Hematol. 15:195203

TESTA, N. G., DEXTER, T. M. 1977: Long-term production of erythroid precursor cells (BFU) in bone marrow cultures. Differentiation 9:193-195

TILL, J. E., MCCULOCH, E. A. 1961: A direct measurement of the radiosensitivity of normal mouse bone marrow cells. Rad. Res.14: 213-222

TRENTIN, J. J.1970: Influence of hematopoietic organ stroma (hematopoietic inductive microenvironment) on stem cell differentiation. In Gordon, A. S. (Ed): Regulation of Hematopoiesis,vol 1. New York, NY, AppletonCentury-Crofts, pp. 616-623

VACEK, A., RAKOVÁ, A., DRUZHININ, Ju. P. 1975: Early changes in the number of haemopoietic stem cells in irradiated young rats. Folia biol. (Praha) 21:199-202

VACEK, A., BARTONÍČKOVÁ, A., TKADLEČEK, L. 1976: Age dependence of the number of the stem cells in haemopoietic tisues of rats. Cell Tissue Kinet. 9: 1-8

VACEK, A., BARTONÍČKOVÁ, A., ROTKOVSKÁ, D. 1979: Decrease in the ability of bone marrow CFU-s to produce macroscopic colonies of haemopoietic tissue in the spleen of partially irradiated young rats. Folia biol. (Praha) 25:188-197

VACEK, A., KOLESNIKOVA, A. I. 1990a: Age dependence of the number of the fibroblasts (CFU-f) and haemopoietic stem cells (CFU-s) in bone marrow and spleen of rats. Folia biol. (Praha) 36:188-193

VACEK, A., BUEVEROVÁ, E. I., MICHURINA, T. N., ROTKOVSKÁ, D., SEROVÁ, L.V. BARTONÍČKOVÁ, A. 1990b: Decrease in the number of progenitors of fibroblasts (CFUf) in bone marrow of rats after a 14-day flight onboard the Cosmos-2044 biosatellite. Folia biol. (Praha) 36:194-197

VACEK, A., BARTONÍČKOVÁ, A., ROTKOVSKÁ, D.1990c: Hydroxyurea as a suppressor of the radioprotective effect of dextran sulfate on bone marrow hemopoietic stem cells in mice. Neoplasma 37:159166

VASSORT, F., FRIENDEL, E., TUBIANA, M. 1971: Efects of hydroxyurea on the kinetics of colony forming units of bone marrow in the mouse. Cell Tissue Kinet. 4: 423-431

VERSELE, S. R. M., VAN DEN HEUVEL, R. L., SCHOETERS, G. E. R.., VANDERBORGHT, O. L. J. 1987 Proliferation activity of stromal stem cells (CFUf) from hemopoietic organs of pre- and postnatal mice. Rad. Res. 11:185-191

WILLIAMS, L. H., UDUPA, K. D., LIPSCHITZ, D. A 1986: Evaluation of the effect of age on hematopoiesis in the C57B1/6 mice. Exp. Hematol. 14: 827-832 